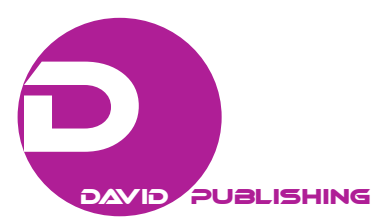

\title{
Financial Variables and Systematic Risk
}

\author{
Rashed Nawaz, Waqar Ahmed, Imran, Sabeela Sabir, Muhammad Arshad, \\ Hazara University, Mansehra, Pakistan \\ Tayyaba Rani \\ Government College University, Faisalabad, Pakistan \\ Adnan Khan \\ University of Wales, Wales, UK
}

\begin{abstract}
The objective of this study is to examine the relationship among financial determinants and systematic risk of cement industry. Five financial variables are utilized as components, i.e. industry size, operating efficiency, liquidity, profitability, and financial leverage in this study. Six years data from 2008 to 2013 have been collected from Karachi Stock Exchange. The consequences of 29 cement industries showed that there is a huge relationship between industry size, operating efficiency, and profitability with 181 systematic risk and results similar to past studies while liquidity and financial leverage have not a significant relationship with beta (systematic risk). Results are profitable for budgetary approach creators and investors to expand the profits.
\end{abstract}

Keywords: cement industries, systematic risk, CAPM

\section{Introduction}

In the assessment of monetary securities, risk is a crucial component that is identified with danger. It has been observationally explored in earlier studies and furthermore checked on in various money related hypotheses. Investors want a high return from investments, which means that risks associated with an investment. Beta is the best angle that ascertained all the risks which are connected with money related choice. Beta is the measure of systematic risk contending the investors about the decision-making framework when operational and financial decisions change which may also bring the change in stock return and may increase the ambiguity related to investment (Breen \& Lerner, 1973).

Beta may be varying from industry to industry. Various researchers investigated different industries to detect the relationship between financial variables and systematic risk. In the view of Holland (2010) there is the probability of an equivalent relative increment in the altered Degree of Financial and Operating Leverage

Rashed Nawaz, Management Sciences/MS, Hazara University, Mansehra, Pakistan.

Waqar Ahmed, Ph.D., Management Sciences/MS, Department of Management Sceinces, Hazara University, Mansehra, Pakistan.

Imran, lecturer in Department of Management Sciences, Hazara University, Mansehra, Pakistan.

Sabeela Sabir, Management Sciences/MS, Department of Management Sciences, Hazara University, Mansehra, Pakistan.

Muhammad Arshad, Management Sciences/MS, Department of Management Sciences, Hazara University, Mansehra, Pakistan.

Tayyaba Rani, Management Sciences/MS, lecturer in Commerce, Government College University, Faisalabad, Pakistan.

Adnan Khan, Business Education/MBA, University of Wales, Wales, UK.

Correspondence concerning this article should be addressed to Waqar Ahmed, Tehsil Mansehra, District Mansehra, Lung Sharif, Post office College Doraha, 21300, Mansehra, Pakistan. 
and Profitability of Firms in Ghana working expense of the organization which has the inclination of diminishing the edge of the working benefit of the association larger than the long haul. As a result, if the variable cost part is dominating among the working expense of the association then there is additionally the probability that the working influence of the organization will decrease and a practically identical impact can be visualized on the net return for a firm with a higher level of budgetary influence.

For a trade on an open market firm in such a business sector, as assumed by financial specialists the danger of a company's stock demonstrated the danger of a firm. High firms' hazard is reflected by higher stock instability and the other way around. Earlier studies on the connection between systematic risk and financial factors primarily employed data through manufacturing sectors. Arslan (2013) investigated the relationship between global diversification and beta.

Logue and Merville (1972), working on casino industry, have realized that the financial factors influence systematic risk fluctuate throughout sectors and also found that casino industries are pretty different from manufacturing industries.

Breen and Lerner (1973) investigated a company's stock return and risk, and a decrease in the beta will increase the firm's worth and vice versa. The significance of systematic risk to organization value has encouraged financial analysts to analyze the correlation between systematic risk and company financial parameters in an effort to determine systematic risk determinants.

According to Zubairi and Farooq (2013) the operating costs which are fixed may not be sufficiently sheltered, thus resulting in a low operating profit. Therefore, an inflow of income or sales increases when a high degree of operating leverage will increase financial performance; sales will show a declining trend when operating profits are reducing rapidly.

The current study has attempted to integrate the companies from cement sector that is listed in Karachi Stock Exchange.

\section{Cement Sector in Pakistan}

The advancement of the concrete part has made fast walks, both in broad daylight and private divisions amid most recent two decades. The historical backdrop of the concrete industry in Pakistan dates back to 1921 when the principal plant was set up at Wah. Pakistan has progressed significantly since freedom in 1947 when the nation had inherited four bond plants having absolute introduced limit of 0.5 million tons, all of which were controlled by India. These units were situated at Karachi, Rohri, Dandot, and Wah. Amid the decade of 1948-1958, quantity of concrete units increased to six.

Because of privatization, the SCCP lost its control over the costs of the bond and thus new concrete plants were built up under private segment. The units working under the SCCP control are old and wasteful utilizing "wet procedure" though the units set up in the private segment are new, productive and use "dry procedure". At present, there are more than 28 bond plants in Pakistan with an introduced limit of more than 19.5 million tons for each annum. The present interest for concrete in Pakistan is around 9.5 million tons for each year.

The cement industry is, in fact, a profoundly imperative portion of the mechanical part that assumes an essential part in the financial advancement. Since concrete is a particular item, requiring a modern base and generation area. For the most part of the concrete organizations in Pakistan are situated close uneven areas that are rich in earth, iron, and mineral limit. Bond ventures in Pakistan are right now working at their greatest limit 
because of the blast in business and industrial construction inside Pakistan. In spite of the fact that an extensive number of concrete assortments are produced in various nations of the world, Pakistan has been taking after sorts of cement like Ordinary Portland bond, Portland Blast Furnace Slag Cement, Sulfate Resisting Cement, and White Cement.

The business involves 29 firms (19 units in the north and 10 units in the south), with the creation limit of 44.09 million tons. The north with a production capacity of 35.18 million tons ( 80 percent) and the south with creation capacity of 8.89 million tons (20 percent), go after the household business sector of more than 19 million tons. There are four remote organizations, three military organizations, and 16 privately owned businesses recorded in the stock trades. The business is partitioned into two expansive locales: the northern area and the southern district.

Table beneath demonstrates the organization's incorporation into the Cement Industry of Pakistan:

Table 1

Cement Industries

\begin{tabular}{ll}
\hline Northern zone & Southern zone \\
\hline Askari Cement Ltd. & A.C. Rohri Cement Limited \\
Bestway Cement Ltd. & Al-Abbas Cement Limited \\
Cherat Cement Ltd. & Attock Cement Limited \\
Dandot Cement Limited & Dadabhoy Cement Limited \\
Dewan Cement Limited & Javedan Cement Limited \\
D.G. Khan Cement (KK) & Pakistan Slag Cement Limited \\
D.G. Khan Cement-II & Thatta Cement Limited \\
Fauji Cement Company & Zeal Pak Cement Limited \\
Flying Cement Limited & Lucky Cement (Pezu) Limited \\
Fecto Cement & Bestway Cement (Chakwal) \\
Gharibwal Cement Ltd. & \\
Kohat Cement Company Limited & \\
Lucky Cement (Karachi) & \\
Maple Leaf Cement & \\
Mustehkam Cement & \\
Pakistan Cement & \\
Pioneer Cement & \\
Bestway Cement Chakwal-I & \\
Askari Cement Ltd. (Nazimpur) & \\
\hline
\end{tabular}

\section{Capital Asset Pricing Model (CAPM)}

The Capital Asset Pricing Model (CAPM) characterizes a straightforward relationship between expected return and risk in the securities market under the hypothesis that equivocal future returns of securities can be portrayed as far as moments of their likelihood courses. The relationship between expected return and hazard is the crucial subject of the advantage valuing hypothesis. The model is for the most part use to ascertain the required rate of return of any venture or portfolio since beta, the business sector, chance likewise incorporate, and extremely valuable to get roughly required rate of return. To figure CAPM, the standard for the danger free rate RF is taken as Pakistan (Karachi) Interbank Offer Rate (KIBOR) comparable to the pertinent yearly eras. For assessing market return RM, changes in the KSE-100 record for each material era are utilized. The Capital Asset Pricing Model (CAPM) is an exceptionally valuable method in the worldwide contributing group for 
figuring the required return of unsafe resource. The Capital Asset Pricing Model (CAPM) is resolved to the estimation of a speculator's budgetary resources when the execution of all financial specialists in money markets is locked in into thought. The reason for this study is to assess the best part to invest Cement sector, to assess the best contributing area to utilize the model (CAPM) which tells required rate of return of every part. Firstly it computes the business sector risk Beta ( $($ ) day by day basis and after this yearly basis, so the Capital Assets Pricing Model (CAPM) is the best model to ascertain the required rate of return.

In this paper, we assess that the Capital Assets Pricing Model (CAPM) is best model to calculate the normal future return of above mentioned points. The outcome that touched base at through information investigation may prompt valuable references about how and which level of CAPM can be utilized as apparatuses for determining stock returns and serving to speculation choices, by and large, and especially for the cement sector in Pakistan.

It is for the most part concurring that speculators request a higher expected return for putting resources into more risk undertakings, or securities. Financial specialists expect the danger of essential securities with the assistance of various models. The Capital Assets Pricing Model (CAPM) is generally utilized by the fund administrators or speculators to find the danger of the venture and to expect the normal return of the stock (Anderson, 2006). The Capital Assets Pricing Model (CAPM) like whatever other models depends on specific suppositions (Damodaran, 2007). Unsystematic danger can be maintained a strategic distance by the portfolio enhancement; however financial specialists are fulfilled for the orderly danger of fundamental security which can't be extended away; the higher the efficient danger, the higher will be the arrival the speculators expect (Lau, Quay, \& Ramsey, 1974). Beta (B) is the measure of precise risk and has positive association with the return.

The Capital Assets Pricing Model (CAPM) adherents and speculators should be fulfilled in two courses: firstly for time estimation of cash and also chance related to the security. To begin with, half of recipe indicates chance free return (RF) that repays the financial specialists for putting cash in any speculation over a time frame. The other portion of the recipe speaks to $[\beta(\mathrm{Rm}-\mathrm{Rf})]$ hazard premium for comportment extra risk. The Capital Assets Pricing Model (CAPM) is the most generally utilized model for specialists to find the financial return. However, it has not generally upheld the model. Since the advancement of the Capital Assets Pricing Model (CAPM), numbers of studies led for testing the legitimacy of the model. The Capital Assets Pricing Model (CAMP) depends on specific presumptions like whatever another model which gave ground to feedback. The presumptions of the Capital Assets Pricing Model (CAPM) are investors holding extended portfolios and single period operation skyline.

The current study has endeavored to determine the systematic risk factors of cement industries listed in Karachi Stock Exchange. Investors want to expand the profits and decrease the chances of risk; therefore, five main financial determinants - industry size, operating efficiency, liquidity, profitability, and financial leverage are used in this study. Next sections described the literature about systematic risk, methodology, results, and conclusion of cement industry.

\section{Literature Review}

There are several forms of risk which can be attributable to different factors, which influence distinct investments to numerous extents. A number of elements impact the majority of investments and are known as betas. Other risks, including sector risks, impact merely a specific sector of the economy. Several risks tend to be specific to a company or resource, and are termed (unsystematic) specific risks. 
Shiller, Fischer, and Friedman (1984) suggest that the significance of an association's basic stock depends on the advantages collected to the shareholders after some time under states of instability. It is fundamental that the money related matters of a firm and business risk calculates the impact of the organization's beta. For instance, utilizing fewer obligations or seeking after a traditionalist development arrangement may prompt lower hazard. Kazi (2004) in his Ph.D. exposition, Sharpe mentioned a number of aspects of Markowitz's portfolio study. At that time, his approach is called the single-index model, which is now recognized as the one-factor model. His key supposition was that security returns relate to each other exclusively by responses to one common factor. In his dissertation, he addressed both normative and positive results. However, under the heading a positive theory of security market behavior, his dissertation covered a result similar to the capital asset pricing models (Sharpe, 1990).

Breen and Lerner (1973) examined that an organization's stock arrival and danger attributes can be impacted by its working, researching, contributing, and working choices. For a given rate of return, a lessening in the beta will build the association's worth and the other way around. Thus, a deliberate danger with respect to an organization's normal stock gives a connection among the business sector worth of an association's shares and corporate conduct. The essentialness of methodical danger to association esteem has urged monetary investigators to break down the connection among deliberate hazard and organization money related parameters with an end goal to decide orderly hazard determinants.

In accordance with Duffie (2010) any kind of scientific theory must lead to propositions which are possibly confirmable as well as replicable by an investigational or empirical statement. There is no exception in asset pricing theory. All over the world, a huge volume of capital investment is used and it has established additional pressure to carry on research in the improvement of suitable techniques for the assessment of these kinds of theories empirically. The literature related to asset pricing is vital to improve our understanding of concerning the systematic risk components that have an effect on investment decisions along with formulating proper models which describe the microstructure associated with financial markets.

Ozkan (2005) examined through his study which held on 2001 the constraint of the ownership structure of British public shareholding companies. The study found two contradictory relationships. There is a negative relationship between profits and liquidity ratio, and between averages of growth with debt. On the other hand, there is a positive relation between company size and degree of financial leverage. Chen (2004) showed the impact of Chinese capital structure on profits; the sample was taken from companies listed in China Stock Market. This study focused also on the industrial sector for the period from 1995 to 2000 . The researcher found a negative relationship between profits and debt, and a positive one between growth opportunities and debt. Also, there is a negative one between companies' size and long-term debt financing.

Mnzava (2009) examined the relationship between corporate tax and beta. The determinants employed integrated efficient leverage ratio, a market value of equity, tax rate, financial risk, return on assets, and growth in earnings and risk of real estate, which demonstrated that corporate tax rate is an essential determinant of beta. Market risk was identified to be favorably related to leverage.

Abid and Mseddi (2004) used the panel data to calculate the degrees of financial leverage and the operating leverage for a company working in United States of America for duration of five years and investigated the relationship relating to the risky nature of the companies and the comparative value. The research recognized a confident impact on the firm value of each financial, operating leverage, therefore the rise in the several examples of leverage of the companies in United States of America. The analysts also 
demonstrated that the surplus return is an optimistic and raising function of financial leverage operating leverage, and systematic risk for sample companies which demonstrate an optimistic relationship associated with sales alteration related with market portfolio returns. Cao and Illing (2010) present that liquidity needs are beneficial in working with systemic liquidity risk in accordance with capital requirements. Amihud (2002) explored that firm size is usually favorably related to a stock's liquidity. Liquidity consequently provides a possible description for the size of impact.

Beta might be exceptional from industry to industry. Different scientists researched distinctive enterprises to recognize the relationship between monetary variables and deliberate danger. J. H. Lee, Y. G. Kim, and M. Y. Kim (2001) utilized the information of aircraft businesses and inferred that the money related to variables has a critical effect on beta.

This study goes for testing the materialness of the model to portray hazard return relationship in the cement part in Pakistan.

\section{Hypotheses}

H0: Industry size has a negative relationship with systematic risk (Beta).

$\mathrm{H} 1$ : Industry size has a positive relationship with systematic risk (Beta).

H0: Operating efficiency is inversely related to systematic risk (Beta).

$\mathrm{H} 2$ : Operating efficiency is positively related to systematic risk (Beta).

H0: Liquidity has an inverse relationship with systematic risk (Beta).

H3: Liquidity is positively associated with systematic risk (Beta).

H0: Profitability has a negative relationship with systematic risk (Beta).

H4: Profitability has a positive relationship with systematic risk (Beta).

H0: Financial leverage is inversely associated with systematic risk (Beta).

H5: Financial leverage is positively associated with systematic risk (Beta).

\section{Research Design}

All the data from 2008 through 2013 are used for this study. The data consist of annual financial reports of all cement industries of Pakistan which are listed in Karachi Stock Exchange and data are also available on the website of state banks of Pakistan. The study used the panel data regression models. There are 29 cross-sectional units and six time periods. In all, therefore, a study has 174 observations.

The economic model of the current study is:

$$
\beta_{\mathrm{it}}=\alpha 0+\alpha 1(\mathrm{FS})_{\mathrm{it}}+\alpha 2(\mathrm{OE})_{\mathrm{it}}+\alpha 3(\mathrm{LIQ})_{\mathrm{it}}+\alpha 4(\mathrm{PROF})_{\mathrm{it}}+\alpha 5(\mathrm{FL})_{\mathrm{it}}+\mu_{\mathrm{it}}
$$

where:

$\beta=$ systematic risk/beta

$\mathrm{FS}=$ firm size

$\mathrm{OE}=$ operating efficiency

LIQ = liquidity

$\mathrm{PROF}=$ profitability

$\mathrm{FL}=$ financial leverage

The variables used in this study are generally measured by the following past studies. Three types of variables are used, discussed below: 
Systematic risk. Systematic risk (beta) is to be considered as a dependent variable. It indicates the volatility of a security's returns relative to the returns of a broad-based market portfolio of securities. There are five independent variables used in current study. These independent variables are firm size, operating efficiency, liquidity, profitability, financial leverage. Systematic risk can be measured with

$$
\beta i=\operatorname{Cov}(\mathrm{Ri}, \mathrm{Rm}) / \operatorname{Var}(\mathrm{Rm})
$$

where $\beta i$ is a systematic risk of ith security, $\mathrm{Rm}$ is market return and Ri return from ith security.

Industry size (IS). It is the size of the firm and measured as the logarithm of total assets at the end of the year. Firm size may influence the financing decision of firms. It is thought that large companies have more possibilities for diversifications because variation bankruptcy rate reduce and possibilities of beta will also minimize. According to Ben-Zion and Shalit (1975), large firms can appreciate reduced unit costs and therefore the probability of productivity decreased the chance of bankruptcy and lower ranges of risk would be the added benefits of substantial companies.

$$
\text { Industry size }=\log \text { (total assets) }
$$

Operating efficiency. It is defined as the ratio between the input to run a business operation and the output gained from the business. Operating efficiency is measured by operating expenses by Net sales. In the view of $\mathrm{Gu}$ and Kim (2002) more operating efficiency indicates producing more profit and as a result of more profit, the beta is decreased.

\section{Operating efficiency $=$ Operating expenses $/$ Net sales}

Liquidity. It is indicator of a company's financial strength (or weakness). It is calculated by taking liquid assets divided by current liabilities. This ratio provides information regarding the firm's liquidity and ability to meet its obligations. Lee and Jang (2007) concluded an adverse connection between systematic risk and liquidity.

$$
\text { Liquidity }=\text { Liquid assets/Total liability }
$$

Profitability. Profitability or return on assets is measured in terms of profit after tax to total assets ratio at the end of financial year. It shows the ability of banks to create profits by utilizing its assets. A company with increased profitability can decrease the chance of any firm's breakdown (Kim, Ryan, \& Ceschini, 2007).

$$
\text { Return on assets }=\text { Net income } / \text { Total assets }
$$

Financial leverage. A firm uses leverage in an attempt to earn returns in excess of the fixed costs of these assets and liabilities, thus increasing the return to common stockholders. When leverage increases beta also increases this relationship which shows that there is an optimistic association among beta and leverage. To measure the leverage debt ratio can be (Hong \& Sarkar, 2007):

\section{Financial leverage $=$ Total debt $/$ Total assets}

\section{Results and Discussion}

The study has explained the outcomes of panel data. Regression analysis was used to analyze the determinants of systematic risk of cement industries of Pakistan. Root test, correlation analysis, and regression analysis were applied for the period of time.

Panel unit root test. Stationary of data is utilized to check the time or regularity pattern. Result showed 
that by utilizing this test, data became regular and there is no spurious problem in the results (see Table 2).

Table 2

Panel Unit Root Test Results

\begin{tabular}{llll}
\hline Variable name & T-statistics & Level or 1st Differ. & Decision \\
\hline Systematic risk & 7.2301 & $\mathrm{I}(0)$ & Stationary \\
Industry size & 20.939 & $\mathrm{I}(0)$ & Stationary \\
Operational efficiency & 22.458 & $\mathrm{I}(0)$ & Stationary \\
Liquidity & -26.938 & $\mathrm{I}(0)$ & Stationary \\
Profitability & 11.456 & $\mathrm{I}(0)$ & Stationary \\
Financial leverage & -5.03 & $\mathrm{I}(0)$ & Stationary \\
\hline
\end{tabular}

\section{Descriptive Statistics}

Industry size has 6.2416 average values with maximum value 8.3157 and minimum value -6.5856 ; operating efficiency has mean value 0.7838 with maximum value 11.718 and minimum value 0.095 ; liquidity has mean value 11.2146 while profitability has 1.1365 average values and financial leverage has 6.3734 (see Table 3).

Table 3

Results of Descriptive Statistics

\begin{tabular}{lllllll}
\hline & B & IS & OE & LIQ & PROF & FL \\
\hline Mean & 1.1450 & 6.2416 & 0.7838 & 11.2146 & 1.1365 & 6.3734 \\
Median & 1.1456 & 0.7745 & 0.4931 & 7.2450 & 1.1450 & 3.2465 \\
Maximum & 3.1388 & 8.3157 & 11.718 & 34.1300 & 3.2700 & 5.3157 \\
Minimum & -27.33 & -6.5856 & 0.0953 & -52.02 & 0.0000 & 4.8141 \\
\hline
\end{tabular}

\section{Correlation Analysis}

Correlation is a method for examining the relationship between two quantitative, consistent factors; therefore, Pearson correlation analysis has been employed for investigating the relationship between all variables here. This technique shows that there is no collinear relationship among independent variables so there is no problem of multicollinearity (see Table 4).

Table 4

\section{Correlation Among Variables}

\begin{tabular}{lllllll}
\hline & B & IS & OE & LIQ & PROF & FL \\
\hline B & 1.0000 & & & & & \\
IS & 0.4695 & 1.0000 & & & & \\
OE & 0.3536 & -0.2743 & 1.0000 & & & \\
LIQ & 0.3840 & -0.1858 & -0.2543 & 1.0000 & & \\
PROF & 0.4695 & -0.1939 & -0.1028 & 0.4695 & 1.0000 & \\
FL & -0.1939 & 0.1157 & -0.1939 & 0.3536 & -0.7626 & 1.0000 \\
\hline
\end{tabular}

Fixed effect model. To empirically analyze the relationship between systematic risk and five independent variables, panel data fixed effect model approach has been used. Results of a fixed effect model are given below.

According to fixed effect model three variables - industry size, operating efficiency, and profitability are significant at the level of 10 percent. R-squared value is 0.5395 that indicates $53.95 \%$ variance in systematic 
risk is due to all explanatory variables. Adjusted R-squared is 0.374981 which indicates that $37.4981 \%$ variance in systematic risk is due to three significant variables - industry size, operating efficiency, profitability while financial leverage and liquidity are not found to be significant. F-statistics value is 17.947 which means overall model is significant.

According to the first hypothesis, industry size increases when beta of that industry decreases in the research, and liquidity is negatively associated with the beta. Theoretically, large companies are apt to have minimal beta for their better capability to decrease the influence of economic, social, and political changes (Sullivan, 1978). The unfavorable influence of size on beta has been verified in much empirical researches, such as those by Kim and Wei (2002).

The second hypothesis shows that operating efficiency has positively associated with systematic risk, which means with the increase of operating efficiency, systematic risk of the cement industries also increase, keeping other factors constant. Chee-Wooi and Chyn-Hwa (2010) have also found the positive and significant relationship between systematic risk and operating efficiency.

Third hypothesis shows that liquidity is negatively associated with the beta. The result shows that increase in liquidity will decrease the systematic risk and the results are not significant. Our result has matched the study of Lee and Jang (2007) who have explored the negative relationship between beta and liquidity but their results are insignificant.

As well as the fourth hypothesis, profitability has a significant and positively impact on beta. This result is matched with the study of Mnzava (2009). The increase in profitability brings a decline in beta value.

The final hypothesis of this study declares that financial leverage is negatively related to beta and this relation is insignificant. Iqbal and Shah (2012) have found an insignificant and negative relationship between beta and financial leverage.

Table 5

Fixed Effect Model

\begin{tabular}{llll}
\hline Variable & Coefficient & T-Statistic & Prob. \\
\hline IS & -0.7565 & -1.8181 & $0.0610^{*}$ \\
OE & 0.3275 & 3.5971 & $0.0002^{*}$ \\
LIQ & -0.0069 & -1.1013 & 0.2494 \\
PROF & 0.1669 & 1.90169 & $0.0539^{*}$ \\
FL & -0.15867 & -0.57793 & 0.6334 \\
C & -0.41584 & -0.18249 & 0.8554 \\
\hline
\end{tabular}

Notes. R-squared = 0.5395; Adjusted R-squared $=0.3426 ;{ }^{*}$ significant at the level of $10 \%$.

\section{Conclusion}

The most essential objective behind an organization is to expand its profits for financial specialists. The return can be maximized by reducing the portion of risk investor's prospects which is very essential and financial policy. Makers should take them into account at the time of policy making. The current research employed the relationship among systematic risk and seven financial variables like industry size, operating efficiency, profitability, liquidity and financial leverage. Six years data of cement industries (2008-2013) listed in Karachi Stock Exchange have been used for estimation. On the basis of earlier studies, five hypotheses have supposed. Fixed effect model has been employed for evaluation. Results explored that three 
variables - industry size, operating efficiency, and profitability are found statistically significant while other two variables - financial leverage and liquidity are not statistically significant. Results of this study are also beneficial for external and internal investors in terms of taking a decision regarding investment in the respective capital market. The study might be beneficial for the mangers of cement industries in order to focus on the variables actually affecting the systematic risk of the firms, and it will make them able to take a more strategic approach to adding value to the organization. This research is very important for investors and finance managers but still there are a few limitations that sample size is small and only one sector is used for analysis. The results of this study may not be generalized on other sectors of the economy. Future research can also employ macroeconomic factors as determinants of beta.

Table 6

\section{Summary of Fixed Effect Modal Analysis}

\begin{tabular}{ll}
\hline Hypothesis & Results \\
\hline 1. Industry size has a negative impact on systematic risk & Accept $\mathrm{H}_{1}$ \\
2. Operating efficiency has a positive relation with systematic risk & Accept $\mathrm{H}_{2}$ \\
3. Liquidity has a negative relationship with systematic risk & ${\text { Reject } \mathrm{H}_{3}}$ \\
4. Profitability has a positive impact on systematic risk & Accept $\mathrm{H}_{4}$ \\
5. Financial leverage has positively association with systematic risk & Reject $\mathrm{H}_{5}$ \\
\hline
\end{tabular}

\section{Application and Recommendations for Future Study}

The study might be beneficial for the mangers of cement industries in order to focus on the variables which actually affect the systematic risk of the firms, it will make them able to take more strategic approach to add value to the organization. Results of this study are also valuable for external and internal investors while taking decision regarding investment in respective capital market. It may be helpful in increasing the prosperity and profitability as well as sales of the cement industries. This research is very important for investors and finance managers but still there are a few limitations that sample size is small and only one sector is used for this research. The results of this study may not be generalized on other sectors of economy. Future research can also employ macroeconomic factors as determinants of beta. They can take large sample size and do comparison with other sectors.

\section{References}

Abid, F., \& Mseddi, S. (2004). The impact of operating and financial leverages and intrinsic business risk on firm value. Journal of Finance and Economics, 44(44), 129-142.

Amihud, Y. (2002). Illiquidity and stock returns: Cross-section and time-series effects. Journal of Financial Markets, 5(1), 31-56. Anderson, S. (2006). Investment management and mismanagement: History, findings, and analysis. Springer Science \& Business Media, 17.

Arslan, Ç. (2013). The systematic risk determinants of tourism industry in Turkey. Eastern Mediterranean University (EMU).

Ben-Zion, U., \& Shalit, S. S. (1975). Size, leverage, and dividend record as determinants of equity risk. The Journal of Finance, 30(4), 1015-1026.

Breen, W. J., \& Lerner, E. M. (1973). Corporate financial strategies and market measures of risk and return. The Journal of Finance, 28(2), 339-351.

Cao, J., \& Illing, G. (2010). Regulation of systemic liquidity risk. Financial Markets and Portfolio Management, 24(1), 31-48.

Chee-Wooi, H., \& Chyn-Hwa, L. (2010). The determinants of systematic risk exposures of airline industry in East Asia. In Proceedings of Regional Conference on Tourism Research, 212.

Chen, J. J. (2004). Determinants of capital structure of Chinese-listed companies. Journal of Business Research, 57(12), 
1341-1351.

Damodaran, A. (2007). Strategic risk taking: A framework for risk management. USA: Pearson Prentice Hall.

Duffie, D. (2010). Dynamic asset pricing theory. Princeton University Press.

Gu, Z., \& Kim, H. (2002). Determinants of restaurant systematic risk: A reexamination. The Journal of Hospitality Financial Management, 10(1), 1-13.

Holland, J. (2010). Banks, knowledge and crisis: A case of knowledge and learning failure. Journal of Financial Regulation and Compliance, 18(2), 87-105.

Hong, G., \& Sarkar, S. (2007). Equity systematic risk (beta) and its determinants. Contemporary Accounting Research, 24(2), 423-466.

Iqbal, M. J., \& Shah, S. Z. A. (2012). Determinants of systematic risk. The Journal of Commerce, 4(1), 47-56.

Kazi, M. H. (2004). Systematic risk factors in Australian security pricing. Doctoral dissertation. University of Western Sydney.

Kim, W., \& Wei, S. J. (2002). Foreign portfolio investors before and during a crisis. Journal of International Economics, 56(1), 77-96.

Kim, W. G., Ryan, B., \& Ceschini, S. (2007). Factors affecting systematic risk in the US restaurant industry. Tourism Economics, 13(2), 197-208.

Lee, J. H., Kim, Y. G., \& Kim, M. Y. (2001). Effects of managerial drivers and climate maturity on knowledge management performance: Empirical validation. PACIS 2001 Proceedings, 77.

Lee, J. S., \& Jang, S. S. (2007). The systematic-risk determinants of the US airline industry. Tourism Management, 28(2), 434-442.

Logue, D. E., \& Merville, L. J. (1972). Financial policy and market expectations. Financial Management, 37-44.

Lau, S. C., Quay, S. R., \& Ramsey, C. M. (1974). The Tokyo stock exchange and the capital asset pricing model. The Journal of Finance, 29(2), 507-514.

Mnzava, I. D. (2009). The significance of corporation tax as a determinant of systematic risk: Evidence using United Kingdom (UK) data. KCA Journal of Business Management, 2(1).

Ozkan, F. G. (2005). Currency and financial crises in Turkey 2000-2001: Bad fundamentals or bad luck? The World Economy, 28(4), 541-572.

Sharpe, S. A. (1990). Asymmetric information, bank lending, and implicit contracts: A stylized model of customer relationships. The Journal of Finance, 45(4), 1069-1087.

Shiller, R. J., Fischer, S., \& Friedman, B. M. (1984). Stock prices and social dynamics. Brookings Papers on Economic Activity, 1984(2), 457-510.

Sullivan, T. G. (1978). The cost of capital and the market power of firms. The Review of Economics and Statistics, $209-217$.

Zubairi, H. J., \& Farooq, S. (2013). A study on factors influencing capital structure of pharmaceutical companies listed on the Karachi Stock Exchange. Available at SSRN 2203634. 